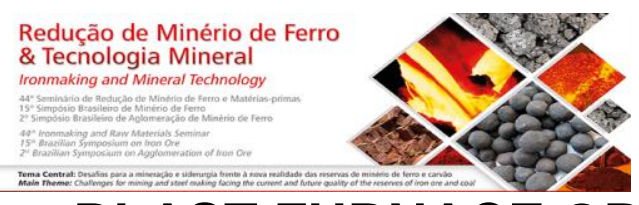

\title{
BLAST FURNACE OPPORTUNITIES FOR REVAMPING PROJECTS*
}

\author{
Jeremy Fletcher ${ }^{1}$ \\ Jason John David Harries²
}

\begin{abstract}
In today's world, the requirement of Steel Producers to revamp and modernize their blast furnaces on-time, safely and with the latest technology is paramount. In addition they must meet the detailed design, construction and safety legislation and regulations, which can be different for the various countries around the world. Siemens MT is renowned for its ability to perform Blast Furnace rebuilds, relines and modernisations within extremely tight time frames and in a safe manner. Modular Blast Furnace construction concepts have been perfected to minimise project duration and plant downtime for furnace rebuilds. Safety and certainty are the keys for success. Siemens MT are constantly introducing new technologies into the market place including cyclone gas cleaning and triple external cone gas scrubber, along with step changes in technology such as dry gas cleaning and dry slag granulation. The economic environment and the continuing requirement for improved environmental performance, drive many of these innovations. This paper describes some of the latest rebuild reference projects of Siemens MT, along with the latest technical innovations installed on these furnaces, and some of the construction methodology used for a safe and secure rebuild.
\end{abstract}

Keywords: Blast furnace; Modernisation; Rebuild; Energy saving.

1 Siemens VAI Metals Technologies, Stockton, California, USA.

2 Siemens VAl Metals Technologies, Stockton, California, USA.

\footnotetext{
* Technical contribution to the 44th Ironmaking and Raw Materials Seminar, $15^{\text {rd }}$ Brazilian Symposium on Iron Ore and $2^{\text {nd }}$ Brazilian Symposium on Agglomeration of Iron Ore, September $15^{\text {th }}$ to $18^{\text {th }}, 2014$, Belo Horizonte, MG, Brazil.
} 


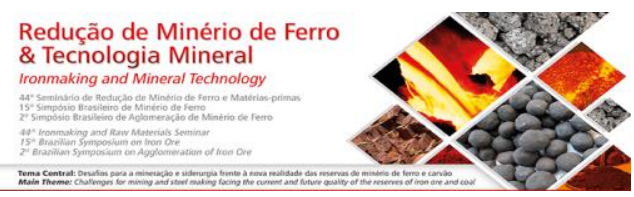

\section{INTRODUCTION}

Siemens MT is the most comprehensive technology provider for the Blast Furnace, and its associated systems. To date we have built over 190 new Blast Furnaces all over the world. Additionally we have carried out 40 rebuilds and provided over 123 Blast Furnace Electrical and Automations systems since the 1980's.

Siemens MT are introducing new technologies into the market place including the cyclone gas cleaning, triple external venturi gas scrubber, along with process step changing concepts such as MERIM and Dry Slag Granulation, that will revolutionise the industry, cutting capital and operational cost, and reduce environmental impact

This paper will present examples of the work that has been carried out, and work being currently done, by Siemens MT to try and modernise the metal industry.

\section{CURRENT EXAMPLES}

\subsection{TSL Port Talbot No.4 Rebuild 2012}

The rebuilt blast furnace will be capable of producing $7465 \mathrm{t} / \mathrm{d}$ and up to $9000 \mathrm{t} / \mathrm{d}$ of hot metal according to the following parameters provided by the Customer.

\begin{tabular}{|c|c|c|}
\hline & Normal & Maximum \\
\hline Production & $7465 \mathrm{t} / \mathrm{d}$ & $9000 \mathrm{t} / \mathrm{d}$ \\
\hline Sinter & $53 \%$ & $53 \%$ \\
\hline Pellet & $42 \%$ & $42 \%$ \\
\hline Ore & $5 \%$ & $5 \%$ \\
\hline Coal Injection & $180 \mathrm{~kg} / \mathrm{thm}$ & $220 \mathrm{~kg} / \mathrm{thm}$ \\
\hline Coke Rate & $336 \mathrm{~kg} / \mathrm{thm}$ & $296 \mathrm{~kg} / \mathrm{thm}$ \\
\hline $\mathrm{O}_{2}$ & $29 \%$ & $34 \%$ \\
\hline Blast Volume & $260-270,000 \mathrm{Nm}^{3} / \mathrm{h}$ & $248-254,000 \mathrm{Nm}^{3} / \mathrm{h}$ \\
\hline Hot Blast Temperature & $1200^{\circ} \mathrm{C}$ & $1250^{\circ} \mathrm{C}$ \\
\hline Normal top pressure range & 1.5 to $1.8 \mathrm{Bar} g$ & 1.5 to $1.8 \mathrm{Bar} g$ \\
\hline Normal hot blast pressure range & 3.0 to 3.6 Bar g & 3.3 to 3.6 Bar g \\
\hline Furnace Top Design Pressure & 2.5 Bar $g$ & 2.5 Bar $g$ \\
\hline Hot Blast Design Pressure & 4.0 Bar $\mathrm{g}$ & 4.0 Bar $g$ \\
\hline Off gas volume (Dry) & $440,000 \mathrm{Nm}^{3} / \mathrm{h}$ & $410,000 \mathrm{Nm}^{3} / \mathrm{h}$ \\
\hline Top gas temperature (max operating) & $150 \mathrm{C}$ & $118 \mathrm{C}$ \\
\hline
\end{tabular}

Figure 1 - PT No.4 Statistics

The furnace rebuild included the following areas:-

- Furnace

- Bustle Main and Tuyere Stocks

- Offtakes, and Downcomer, with Cyclone inlet isolation

- Dirty Gas Main and U Seal, and Goggle valve.

- Cyclone and Gas Cleaning Plant

- Furnace Cooling Systems

- Associated Instrumentation

\footnotetext{
* Technical contribution to the 44th Ironmaking and Raw Materials Seminar, 15rd Brazilian Symposium on Iron Ore and $2^{\text {nd }}$ Brazilian Symposium on Agglomeration of Iron Ore, September $15^{\text {th }}$ to $18^{\text {th }}, 2014$, Belo Horizonte, MG, Brazil.
} 
\& Tecnologia Mineral

tom tom ore

\subsection{Furnace Shell}

The furnace shell was replaced. The new shell was designed to suit the furnace lines, associated plate cooler openings, throat armour branches, and probe branches.

\begin{tabular}{|l|l|l|}
\hline & New Shell and Refractory & Original 1992 Shell and Refractory \\
\hline Working Volume & $2388 \mathrm{~m}^{3}$ & $2134 \mathrm{~m}^{3}$ \\
\hline Hearth Diameter & $11.2 \mathrm{~m}$ & $10.8 \mathrm{~m}$ \\
\hline Throat Diameter & $8.6 \mathrm{~m}$ & $8.2 \mathrm{~m}$ \\
\hline Belly Diameter & $12.67 \mathrm{~m}$ & $12.2 \mathrm{~m}$ \\
\hline Working Height & $25.1 \mathrm{~m}$ & $24 \mathrm{~m}$ \\
\hline Number of Tuyeres & 30 & 30 \\
\hline Number of Tapholes & 2 & 2
\end{tabular}

Figure 2 - PT No.4 Furnace Design Parameters

\subsection{Stoves}

As part of the BF4 rebuild programme, a new stove (No.9) was built before the furnace rebuild period in June 2012. The construction of the No.9 stove facilitated, sequential demolition and rebuild of stoves 10 and 11 during and beyond the furnace rebuild period.

The required blast duties from the new No.9, No.10 and No.11 stoves were as follows.

\begin{tabular}{|c|c|c|}
\hline & $\begin{array}{l}1350^{\circ} \mathrm{C} \\
\text { Dome } \\
\text { Temperature }\end{array}$ & $\begin{array}{l}1400^{\circ} \mathrm{C} \\
\text { Dome } \\
\text { Temperature }\end{array}$ \\
\hline $\begin{array}{l}\text { Normal Operating Straight Line Blast Temperature }\left({ }^{\circ} \mathrm{C}\right) \\
\text { (Measured in the hot blast main just prior to the bustle } \\
\text { main) }\end{array}$ & 1210 & 1245 \\
\hline Cold Blast Temperature ${ }^{\circ} \mathrm{C}$ & 160 & 160 \\
\hline $\begin{array}{l}\text { Blast Pressures:- } \\
\text { Design Pressure bar.g } \\
\text { Safe Operating Limit bar.g } \\
\text { Normal Operating Pressure bar.g }\end{array}$ & $\begin{array}{l}4.0 \\
3.7 \\
3.6\end{array}$ & $\begin{array}{l}4.0 \\
3.7 \\
3.6\end{array}$ \\
\hline \multicolumn{3}{|l|}{ Design Blast Volumes: } \\
\hline Oxygen Enrichment \% & 9 & 9 \\
\hline Moisture Addition $\mathrm{g} / \mathrm{Nm}^{3}$ & 15 & 15 \\
\hline $\begin{array}{l}\text { Total Blast Volume } \mathrm{Nm}^{3} / \mathrm{h} \\
\text { (Including above } \mathrm{O}_{2} \& \mathrm{H}_{2} \mathrm{O} \text { additions) }\end{array}$ & 270000 & 270000 \\
\hline Assumed Ambient Temperature ${ }^{\circ} \mathrm{C}$ & 15 & 15 \\
\hline
\end{tabular}

Figure 3 - PT No.4 Stove Blast Duties

After completing the heat and mass balance calculations to determine the optimum operating conditions and physical dimensions of the stove, the following stove parameters describe the new stoves installed (No.9, 10 \&11).

\footnotetext{
* Technical contribution to the $44^{\text {th }}$ Ironmaking and Raw Materials Seminar, $15^{\text {rd }}$ Brazilian Symposium on Iron Ore and $2^{\text {nd }}$ Brazilian Symposium on Agglomeration of Iron Ore, September $15^{\text {th }}$ to $18^{\text {th }}$, 2014, Belo Horizonte, MG, Brazil.
} 
2.4 Overall Dimensions

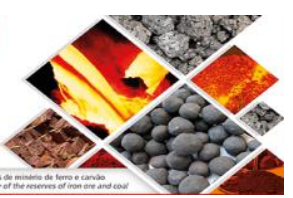

Dome Type

Mushroom

Inside Shell Diameter mm

8623

Approx. Overall Height of Stove mm

43,000

\subsection{Cyclone}

The dirty gas system utilises a tangential cyclone. The cyclone was designed to maximise collection efficiency with a consequential reduction in dust loading at the scrubber. The efficiency of the cyclone is approximately 80 to $85 \%$. The cyclone installed was a first for the company, a triple inlet cyclone.

The cyclone was internally lined to reduce wear. Furthermore, internally painting with anti-corrosion product for prevention of acid attack is not proposed. Such coatings are not considered necessary or appropriate since the temperature of the gas in the cyclone is rarely below the dew-point and internal coatings require a wet environment to prevent dry-out and flaking.

The dust is removed by two separate legs. Each leg comprised the following in descending order:

- Two dome isolation valves

- One intermediate hopper

- One dome isolation valve

- One dust control valve

- One Pugmill

The dust from the Cyclone falls into a pressurised intermediate vessel capable of about 2 hour's storage. However it will only store for 1 hour and be repeatedly emptied throughout the day. The pressure within the vessel is maintained with Nitrogen. The vessel is determined as full and empty using a weighing system. In addition to controlling the filling and emptying of the Cyclone, by totalising the weighed dust, an inventory of the dust leaving the Cyclone can be achieved.

When the hopper is full the inlet isolation valves closes and the outlet isolation valves opens. The dust flow control valve will move to a set position to ensure an acceptable flow of dust to a pug mill. The dust is then deposited into a skip via the pug mill.

\subsection{RINL VIZAG BF1 Rebuild (2012)}

Visakhapatnam Steel Plant (VSP) owned by Rashtriya Ispat Nigam Limited (RINL) was producing about 4.0 million tons per annum (Mtpa) of hot metal from their existing two blast furnaces. VSP has been operating the blast furnace \#1 'Godavari', which is installed at Visakhapatnam, since March 1990. VSP intends to carry out a Category-I capital repair of blast furnace \#1 which includes improvements in the energy efficiency and working environment of the furnace. The furnace operating conditions, size and parameters are shown in the tables below.

\footnotetext{
* Technical contribution to the $44^{\text {th }}$ Ironmaking and Raw Materials Seminar, $15^{\text {rd }}$ Brazilian Symposium on Iron Ore and $2^{\text {nd }}$ Brazilian Symposium on Agglomeration of Iron Ore, September $15^{\text {th }}$ to $18^{\text {th }}$, 2014, Belo Horizonte, MG, Brazil.
} 


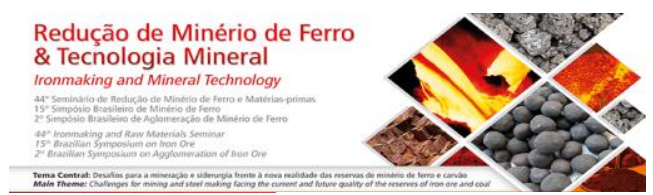

\begin{tabular}{l}
\hline Hot metal production (mtpa) \\
\hline Production (tonnes per day) \\
\hline Productivity, (t/d/m³ U.V.) \\
\hline Useful Volume $\left(\mathrm{m}^{3}\right)$ \\
\hline Working Days per year \\
\hline Sinter Rate (\%) \\
\hline Sized Ore Rate (\%) \\
\hline Coke Ash (\%) \\
\hline Coke Rate - hard + nut (kg/tHM) \\
\hline PCl (kg/tHM) \\
\hline Operating Top Pressure (barg) \\
\hline Hot Blast Temperature ( $\left.{ }^{\circ} \mathrm{C}\right)$ \\
\hline O enrichment to blast $(\%)$ \\
\hline Steam injection (g/Nm $\left.{ }^{3}\right)$ \\
\hline
\end{tabular}

\begin{tabular}{|c|}
\hline 2.0 \\
\hline 5,715 \\
$\sim 1.79$ \\
\hline 3,200 \\
\hline 350 \\
\hline 78 \\
\hline 22 \\
\hline 15 \\
\hline 543 \\
0 \\
\hline 2.0 \\
\hline 1050 \\
\hline$\sim 1.5$ \\
\hline $35-40$ \\
\hline
\end{tabular}

Figure 1 - Vizag Furnace Statistics (before rebuild)

\begin{tabular}{|l|c|l|}
\multicolumn{1}{c|}{ Data } & Value & \multicolumn{1}{c|}{ Units } \\
\hline Furnace working volume *** & 3,416 & $\mathrm{~m}^{3}$ \\
\hline Furnace inner volume *** & 3,891 & $\mathrm{~m}^{3}$ \\
\hline Maximum operating top pressure & 2.44 & $\mathrm{~kg} / \mathrm{cm}^{2} \mathrm{~g}$ \\
\hline System design blast pressure (at furnace) & 4.59 & $\mathrm{~kg} / \mathrm{cm}^{2} \mathrm{~g}$ \\
\hline Hearth diameter & 12.140 & $\mathrm{~m}$ \\
\hline Hearth area & 115.75 & $\mathrm{~m}^{2}$ \\
\hline Productivity per hearth area & 61.77 & $\mathrm{t} / \mathrm{d} / \mathrm{m}^{2}$ \\
\hline Number of tuyeres & 32 & $\mathrm{off}$ \\
\hline
\end{tabular}

Figure 2 - Vizag Furnace Design Parameters (after rebuild)

In order to achieve a $10 \%$ increase in production during the rebuild, the furnace productivity increased to $2.02 \mathrm{t} / \mathrm{d} / \mathrm{m} 3 \mathrm{I}$ I.V. (Inner Volume) (compared to the current productivity of $+1.79 \mathrm{t} / \mathrm{d} / \mathrm{m} 3 \mathrm{I}$.V.) and simultaneously the furnace volume is increased to $3,891 \mathrm{~m} 3 \mathrm{I} . \mathrm{V}$. The future productivity is within world "norms" for furnaces with consistent quality raw materials, and similar to current Indian furnaces being commissioned.

The reconfigured furnace design incorporates the following features in order to increase the I.V of the rebuilt No.1 Furnace:

- The depth of sump below the taphole equals approximately $20.6 \%$ of the hearth diameter. This compares to the minimum sump depth standard of $20 \%$ of hearth diameter.

- Large belly diameter. This is appropriate for high coal injection flows and reduction of heat load on the cooling system.

- Modern Thin walled Copper Staves increases the free volume of the furnace.

\subsection{Furnace Cooling System}

To maximise the campaign life of the blast furnace a stave cooler concept is retained. Stave coolers offer direct protection of the blast furnace shell by providing a homogeneous cooling shield on which accretions can form thereby giving abrasion resistance against the continuously moving furnace burden.

\footnotetext{
* Technical contribution to the 44 ${ }^{\text {th }}$ Ironmaking and Raw Materials Seminar, $15^{\text {rd }}$ Brazilian Symposium on Iron Ore and $2^{\text {nd }}$ Brazilian Symposium on Agglomeration of Iron Ore, September $15^{\text {th }}$ to $18^{\text {th }}, 2014$, Belo Horizonte, MG, Brazil.
} 


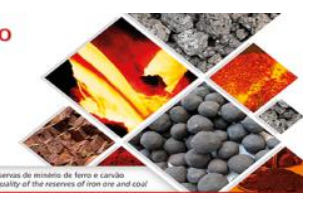

2.8 Bosh, Belly and Lower Stack

In the areas of the furnace subjected to high heat loads, i.e. bosh, belly and lower stack, the staves are specified as cast copper with 4 internal cooling channels.

The cooling pipe connections have expansion bellows so the staves will be free to expand without overstressing the welded connection between the cooling pipes and stave.

\subsection{Hearth, Tuyere Area, Middle and Upper Stack}

In the hearth and tuyere areas of the furnace plain faced cast iron staves with a cast-in cooling pipe are specified. The middle and upper stack are also be specified with cast iron staves with 4 cast-in cooling pipes. Finally, above the last upper stack stave row cast iron throat staves with grooves are specified to provide abrasion protection at the furnace stockline level.

The copper and cast iron SIMETAL Furnace Staves design is an integral part of the furnace and will provide the following advantages:

- Highest life expectancy due to quality control during manufacture.

- Increased useful volume due to optimised stave profile.

- The copper stave fixed in the centre using a welded pin, controlling differential movement between staves.

- Pipe connections fitted with bellows type expansion joints on the copper staves to compensate relative thermal movements between the staves and shell.

\subsection{Cooling Circuits}

The primary cooling areas of the blast furnace are split into three separate circuits. Two closed cooling water circuits will supply:

- Hearth and Tuyere Staves, Underhearth and Taphole Cooling

- Bosh, Belly, Stack and Throat Staves, Hot Blast and Backdraught Valves.

The tuyere bodies and tuyere jumbo coolers are on an open circuit with booster pumps providing high pressure water for the tuyere noses and furnace top.

The furnace cooling low pressure open circuit will supply the following:

- Tuyere Jumbo Coolers

- Tuyere Body

- Miscellaneous Employer users

The furnace cooling high pressure open circuit supplies the following:

- Tuyere Nose

- Furnace Top Hydraulic Cooler

- Furnace Top Burden Sprays

- Miscellaneous Employer users

The design for the closed circuit system incorporates the following features:

- Basic closed circuit system using soft water.

- A separate circuit comprising the tuyere and hearth staves: Cooling water will be introduced via two ring mains one ring main for $\mathrm{H} 1, \mathrm{H} 2$ and $\mathrm{H} 3$ and the second for $\mathrm{H} 4$ and TU1. This allows the existing design single pass staves to be used.

\footnotetext{
* Technical contribution to the $44^{\text {th }}$ Ironmaking and Raw Materials Seminar, $15^{\text {rd }}$ Brazilian Symposium on Iron Ore and $2^{\text {nd }}$ Brazilian Symposium on Agglomeration of Iron Ore, September $15^{\text {th }}$ to $18^{\text {th }}$, 2014, Belo Horizonte, MG, Brazil.
} 
- A second circuit comprising the cooling water will be introduced into the belly stave to flow up through the stack staves exiting at the throat staves.

- The design will preclude boiling due to overpressure.

The emergency water for the closed cooling system is supplied by VSP to the staves supply ring mains and flows up through the staves to exit at the throat staves ring mains. Emergency water requirement is $2 / 3$ of normal flow for both soft and industrial circuits. The existing EOHT capacity and head are adequate to meet the desired requirement for all water systems.

\subsection{Kerdemir Merim Modernisation (2014)}

Demands placed on availability, product quality and productivity of iron making plants are continuously increasing, and these can only be met with advanced solutions suitable for the rugged iron- and steelmaking environment. At the same time, stricter environmental regulations necessitate extensive investments, and these are having a direct impact on iron making plants with their high quantity of environmental emissions. As plant designers, our job is to offer the best possible solutions that simultaneously satisfy environmental requirements and economic necessity.

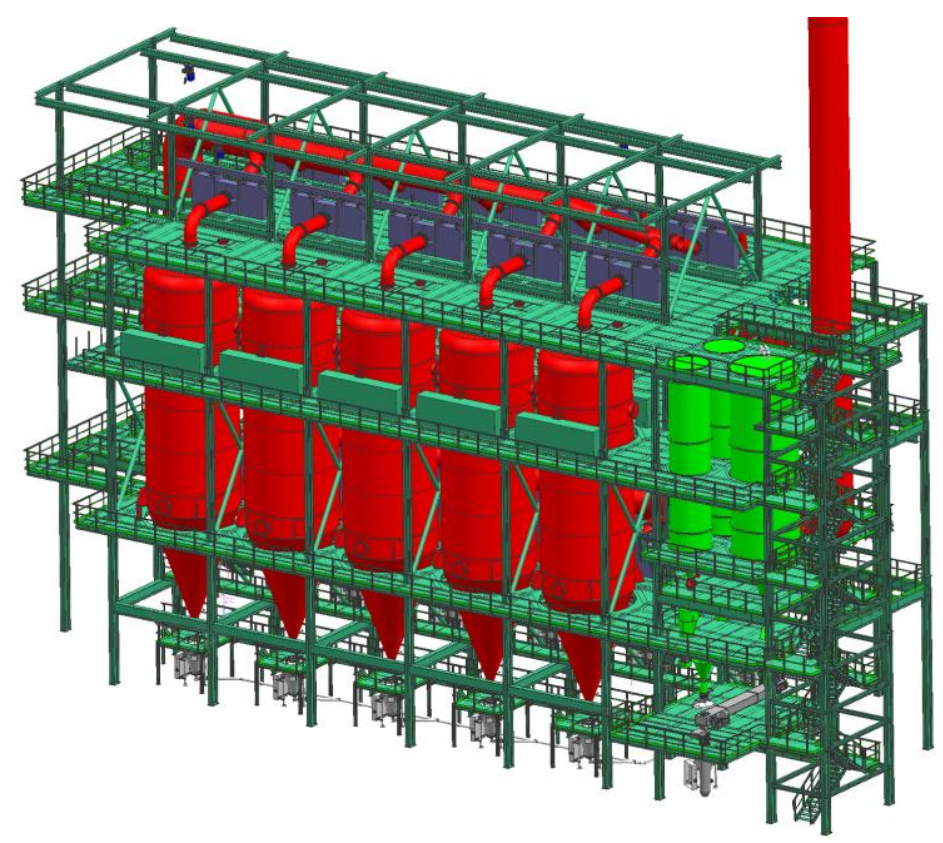

Figure 3 - Concept model of MERIM

Conventional wet-type top gas cleaning technologies have a high water demand and require expensive sludge and waste water treatment. In addition, wet cleaning leads to substantial pressure and temperature drops which result in reduced efficiency of the downstream top gas recovery turbine. A fully satisfactory, environmentally compatible solution for the treatment of top gas from the Iron making process has not existed up until now. In response to this challenge, Siemens VAI Metals Technologies recently developed the Simetal Merim process, which stands for Maximized Emission Reduction

\footnotetext{
* Technical contribution to the $44^{\text {th }}$ Ironmaking and Raw Materials Seminar, $15^{\text {rd }}$ Brazilian Symposium on Iron Ore and $2^{\text {nd }}$ Brazilian Symposium on Agglomeration of Iron Ore, September $15^{\text {th }}$ to $18^{\text {th }}$, 2014, Belo Horizonte, MG, Brazil.
} 
and energy recovery in iron making. In a series of successive treatment steps the dust and harmful components present in the off-gas are removed to levels previously unattained with conventional wet-type top gas-treatment techniques. The Simetal Merim is mainly designed for blast furnace top gas cleaning but can also be successfully applied for Simetal Corex and Simetal Finex.

The new system includes a cyclone for coarse dust separation and a high-performance fabric filter for fine dust removal. In order to solve the problem of temperature fluctuations in the top gas, Siemens VAl Metals Technologies developed a gas conditioning concept which allows for safe operation even at low and high temperatures. This system consists of a burden burner and an advanced burden spray.

Using this green solution, energy consumption and land filling can be reduced to currently unachieved levels. The cleaned gas meets both current and future emission regulations and the $\mathrm{CO}_{2}$ footprint can be significantly reduced.

The long product manufacturer, Kardemir, is currently erecting at the Karabük site a new blast furnace with an interior volume of 1,650 cubic meters and an annual production capacity of circa 1.2 million tons. In order to achieve optimum cleaning of the top gas and efficient separation of the dust into usable and non-usable portions, Kardemir decided for the MERIM plant. MT is responsible for the basic and detail engineering of the plant and will deliver all key components. The plant is designed as a two-stage drytype de-dusting system and engineered for the cleaning of up to 400,000 Nm3 of top gas per hour. Coarse dusts are separated in a specially designed centrifugal separator (cyclone), after which the fine dust is collected in fabric filters. The Merim plant reduces the total dust content in the off-gas to less than three milligrams per Nm3.

As compared to conventional wet-type de-dusting plants, the Merim solution harbours a number of advantages, one of which being that neither wastewater nor sludge is accumulated. Water or sludge treatment is therefore completely unnecessary. This reduces the space requirements of the entire system and minimizes the investment costs. The pressure drop and temperature loss in the top gas are also significantly minimized. This makes it possible to increase the energy output in the top-gas turbines by roughly 25 percent. The new cyclone also improves the separation of recyclable ironcontaining dust fractions from the waste fractions. Roughly 85 percent of the dust is separated in the cyclone, where the separation efficiency of the usable fraction reaches 90 percent. This fraction can be used, for example, in the sinter plant. Dust with a high fraction of heavy metals, such as zinc, are efficiently separated and can be treated in different processes.

\subsection{Voestalpine Stahl Linz Blast Furnace A - Dry Slag Granulation Pilot Plant}

Through the years that blast furnace technology has existed, many improvements have been made in the field of energy saving and recycling. However, one area of the Blast Furnace process has never been modernised in this fashion, and that is the slag granulation plant. In the early 1900 it was found that the use of slag in cement and concrete was beneficial to the material strength over long periods of time, and so created a financial benefit to blast furnace operators in the selling of a by-product that would have normally ended in a landfill.

\footnotetext{
* Technical contribution to the $44^{\text {th }}$ Ironmaking and Raw Materials Seminar, $15^{\text {rd }}$ Brazilian Symposium on Iron Ore and $2^{\text {nd }}$ Brazilian Symposium on Agglomeration of Iron Ore, September $15^{\text {th }}$ to $18^{\text {th }}$, 2014, Belo Horizonte, MG, Brazil.
} 


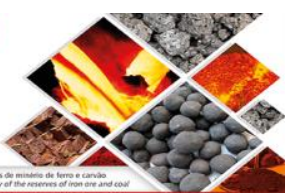

The slag must be in a granulated form, and have certain composition for use in cement and concrete, and so must go through an additional process. Once the slag has been separated from the pig iron, it is transported to the granulation plant, where it is rapidly cooled using water to solidify the product, or dumping into open slag pits to cool down using the ambient environment. The water cooled method also requires an additional input of drying energy to ensure the usability of the slag in the cement or concrete industry.

Both scenarios do not allow for recovery of the heat lost from the slag, which is one of the largest heat reservoirs in the iron making process, and the estimated savings from a typical furnace through heat recovery and reuse is significant. With this in mind Siemens MT, in partnership with Voestalpine Stahl, University of Leoben, and FEhs, a solution in the form of Dry Slag Granulation was developed. The slag is cooled by feeding the molten product onto a variable speed rotating cup, which forces the slag outward towards the inner surface of the associated containment vessels, the slag is cooled be passing through a the cooled atmosphere within the vessel. The process is designed so the slag is sufficiently cooled before hitting the vessel surface, and then cooled further through a static water jacket.

The solidifying granules fall into a mobile bed of granules that is designed to ensure that there is no agglomeration. The bed is kept in motion by the design of the cooling air distributor that imparts a circumferential motion to particles. The cooling particles fall into a discharge trough that forms an inner annulus. Some are recycled to intercept the solidifying particles in flight from the cup to assist in their cooling. The remainder are further cooled as they are blown towards discharge ports and thence on to conveyors for transport to storage. Some particles are lifted out of the cooling bed and scour the chamber walls, further reducing the possibility of solidifying droplets, in flight from the cup, sticking on the walls. Any carryover of particles in the cooling air is minimised by flow straighteners in the upper levels of the chamber that are designed to reduce velocities in this region. The air is finally discharged via a stack or stacks. For blast furnace slag applications, slag wool arresters and collectors are included.

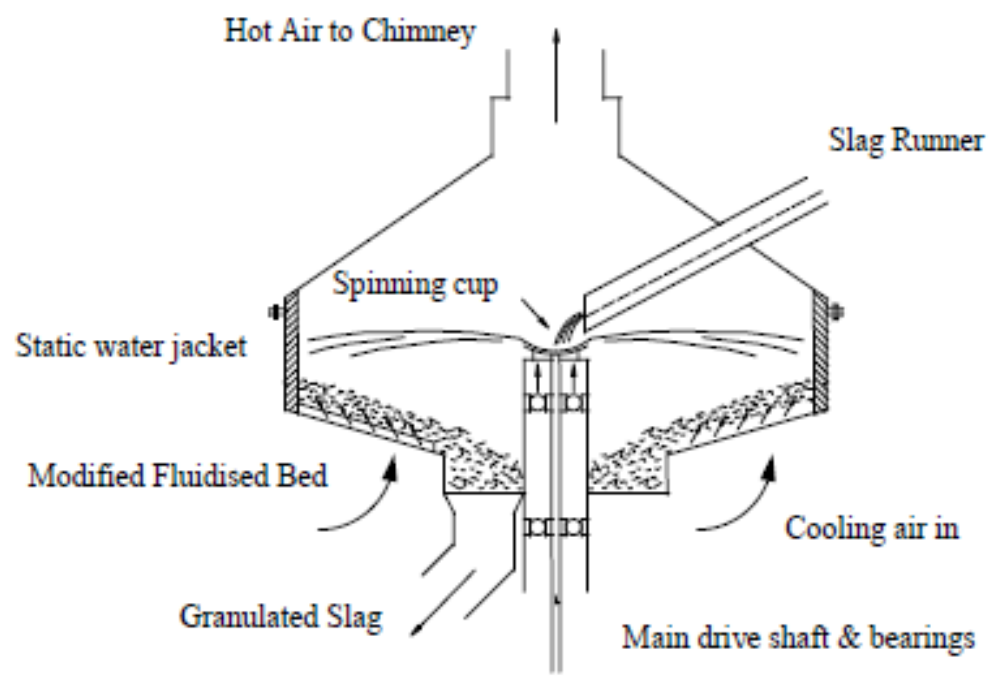

Figure 4 - Concept drawing of dry slag granulation process

\footnotetext{
* Technical contribution to the 44 ${ }^{\text {th }}$ Ironmaking and Raw Materials Seminar, $15^{\text {rd }}$ Brazilian Symposium on Iron Ore and $2^{\text {nd }}$ Brazilian Symposium on Agglomeration of Iron Ore, September $15^{\text {th }}$ to $18^{\text {th }}$, 2014, Belo Horizonte, MG, Brazil.
} 


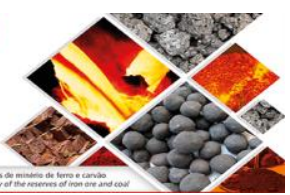

Studies have shown that the potential energy available in the waste heat emitted from the slag granulation process is approximately $1.5 \mathrm{GJ} / \mathrm{t}$ of slag, which can be utilised in a multitude of methods, such as steam and power generation, stove preheating. This energy saving has been estimated to save the blast furnace operations approximately $€ 3.5 \mathrm{~m}$ per, with lower operating costs saving an extra $€ 1.8 \mathrm{~m}$ per annum (both values based on a typical furnace size of $6000 \mathrm{THM} /$ day). Additional benefits include lower initial capital expenditure than a conventional wet system, no additional processes required for use as a cement additive, and significantly lower sulphur emissions.

The project is currently in its second phase, with a full sized pilot plant to be installed at Voestalpine Stahl Blast Furnace A. The DSG plant will be able to produce granulated slag at a nominal rate of $1.5-2 \mathrm{te} / \mathrm{min}$, with a maximum rate of $6 \mathrm{te} / \mathrm{min}$, and testing will commence to seek optimal air flow and granulate dispersal to ensure maximum offtake temperatures whilst maintaining high quality slag product for resale. Phase 3 will consist of installing power generation systems and combustion air pre-heating equipment to quantify the potential benefits from recycling the extracted heat.

\section{CONCLUSIONS}

From the example projects shown that in the current global situation, companies are showing a growing interest in rebuilding aging Blast Furnaces and modernising them to tackle the present market. Siemens MT has responded to their demands by supply a service that is efficient, strict adherence to time constraints, of high quality, and constantly evolving. The future developments shown will not only increase the overall efficiency of the blast furnace process, but reduce the initial and overall expenditures in the lifetime of the plant. These ideals have shown to be crucial for the survival of plants in present day.

\section{BIBLIOGRAPHY}

1 Harries JJD. Blast furnace - new and rebuild opportunities. Siemens MT. Report number: 1, 2012.

2 Mason D. Simetal Merim . Siemens MT. Report number: 1, 2012.

3 McDonald IJ. Dry slag granulation - the environmentally friendly way to making cement. Siemens MT. Report number: 1, 2012.

4 Harries JJD. Blast furnace - new and rebuild opportunities. Siemens MT. Report number: 1, 2012.

5 Mason D. Simetal Merim . Siemens MT. Report number: 1, 2012.

6 McDonald IJ. Dry slag granulation - the environmentally friendly way to making cement. Siemens MT. Report number: 1, 2012.

\footnotetext{
* Technical contribution to the $44^{\text {th }}$ Ironmaking and Raw Materials Seminar, $15^{\text {rd }}$ Brazilian Symposium on Iron Ore and $2^{\text {nd }}$ Brazilian Symposium on Agglomeration of Iron Ore, September $15^{\text {th }}$ to $18^{\text {th }}$, 2014, Belo Horizonte, MG, Brazil.
} 